\title{
The Effect of Coronavirus Disease 2019 on Reproduction System and Fertility
}

\author{
Muhammad Fidel Ganis Siregar* (D), Effinia Kamila Hanum Siregar \\ Department of Obstetrics and Gynecology, Faculty of Medicine, Universitas Sumatera Utara, Medan, Indonesia
}

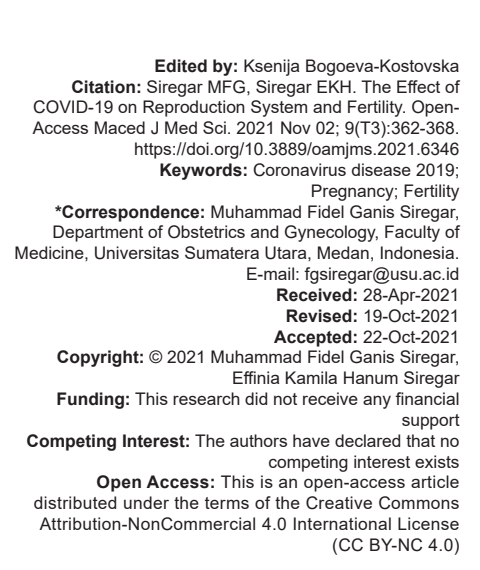

\section{Introduction}

Coronavirus disease 2019 (COVID-19) is caused by severe acute respiratory syndromecoronavirus-2 (SARS-CoV-2) which is an acute infectious disease that mostly affects the respiratory system, first discovered in December 2019 in Wuhan, China. It was then declared a pandemic by the World Health Organization on March 11, 2020 [1], [2]. As of October 9, 2020, SARS-CoV-2 was recorded to have infected more than 235 countries and 36,361,054 people globally, and 1,056,186 people died from COVID-19. In early October 2020, it was reported that the rate of increase in new cases reached 300,000 cases per day. The United States, India, and Brazil are the three countries with the highest total cases of the spread of COVID-19 in the world [3].

There were 324,658 confirmed cases of COVID-19 in Indonesia until October 9, 2020, of which 247,667 people had recovered and 11,677 people died. Based on data released by the Medan City Health Office, there were 6090 COVID-positive patients in Medan City as of October 9, 2020, 260 people died, and 3938 patients recovered. This figure may continue to grow [3], [4], [5].
This virus enters the target cells through the glycoprotein spike SARS-CoV-2 (S) which binds to the host's angiotensin-converting enzyme 2 (ACE2) receptor. Moreover, host cellular proteases such as transmembrane serine two protease (TMPRSS2) then cleavage viral $S$ protein which allows fusion of the viral and host cell membranes permanently [1]. This study aimed to report the effect of COVID-19 on the reproduction and fertility system. We hypothesized that there is an effect of COVID-19 on pregnancy and fertility.

\section{Pathogenesis of COVID-19: ACE2 as SARS-CoV and SARS-CoV2 Receptors}

ACE2 is a functional receptor by which SARSCoV enters the target host cell. The transmembrane nail glycoprotein (protein S) of SARS-CoV binds to the ACE2 cell membrane; SARS-CoV then attaches to the target cell, followed by priming the S-SARS-CoV protein by cell surface proteases, such as TMPRSS2, $11 \mathrm{~A}, 11 \mathrm{D}$, and 11E allowing fusion between the virus 
and the cell membrane resulting in the entry of SARS$\mathrm{CoV}$ and replication occurs in target cells. In addition, phosphatidylinositol 3-phosphate 5-kinase, two-pore channel subtype 2, cathepsin L, and cathepsin B, which are a lysosome, are also reported to be important molecules that play a role in the entry of SARS-CoV-2 to the target cell. Low ACE2 levels greatly reduced infection and viral replication in the SARS-CoV infection trial in mice. Thus, the S-SARS-CoV protein and ACE2 binding are very important in the process of SARS-CoV infection [6], [7].

\section{Effects of SARS-CoV-2 on the Male Reproductive System}

In early October 2020, it was reported that the rate of increase in new cases reached 300,000 cases per day. There were 324,658 confirmed cases of COVID-19 in Indonesia until October 9, 2020, of which 247,667 people had recovered and 11,677 people died. Based on data released by the Medan City Health Office, there were 6090 COVID-positive patients in Medan City as of October 9, 2020, 260 people died, and 3938 patients recovered (Table 1 ). This figure may continue to grow [3], [4].

Experts are currently focusing on studying the characteristics of the SARS-CoV-2 virus and the mechanisms that lead to the development of the COVID-19 disease. In fact, intense efforts are being made to find a possible cure or vaccine. Then, there are only limited studies which have explored the possible effects of SARS-CoV-2 infection and its sequel on the reproductive systems of both men and women, as well as the potential outcomes in the context of reproductive medicine [6].

The Human Protein Atlas database reports the expression of the ACE2 receptor in male and female reproductive organs. These receptors have an important role in sperm function and the fertilization of oocytes. Increased expression of the ACE2 receptor was reported in testicular tissue, particularly in spermatogonia, Sertoli, and Leydig cells, as well as in prostate epithelial cells, fibroblasts, and pericytes (Figure 1) [8], [9].

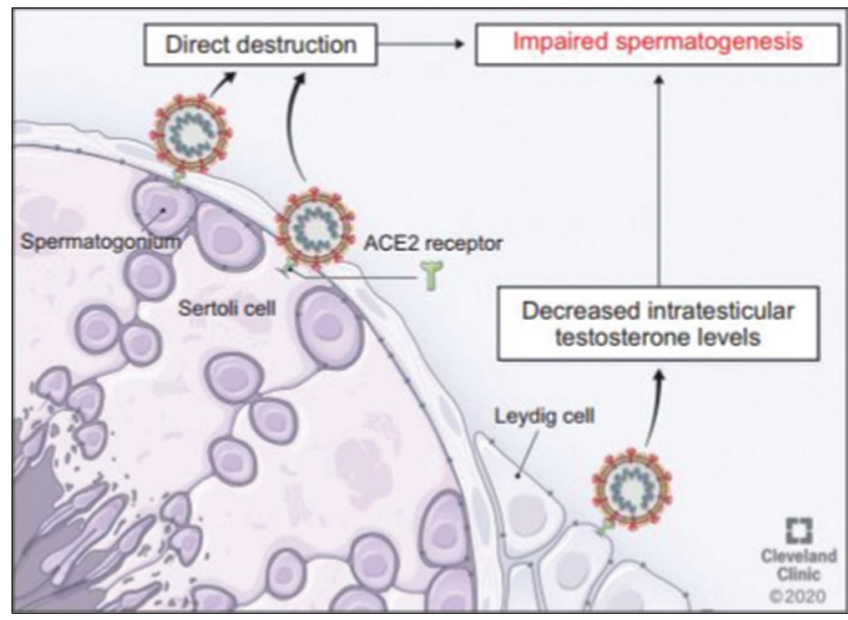

Figure 1: Severe acute respiratory syndrome coronavirus 2 in spermatogenesis [8]

The effects of SARS-CoV-2 on the male reproductive system are not fully explained. The effects of SARS-CoV-2 on the male reproductive system are

Table 1: COVID-19 data in Indonesian Provinces4

\begin{tabular}{|c|c|c|c|c|c|c|c|c|c|c|}
\hline \multirow{2}{*}{ No. } & \multirow{2}{*}{ Province } & \multicolumn{3}{|c|}{ Total cases on October 9, 2020} & \multicolumn{3}{|c|}{ Recovered cases on October 9,2020} & \multicolumn{3}{|c|}{ Deceased cases on October 9, 2020} \\
\hline & & Until October 8, 2020 & October 9, 2020 & Total & Until October 8, 2020 & October 9, 2020 & Total & Until October 8, 2020 & October 9,2020 & Total \\
\hline 1 & Aceh & 5423 & 123 & 5546 & 3492 & 93 & 3585 & 204 & 2 & 206 \\
\hline 2 & Bali & 9759 & 138 & 9897 & 8317 & 138 & 8455 & 313 & 4 & 317 \\
\hline 3 & Banten & 6570 & 141 & 6711 & 4768 & 86 & 4854 & 197 & 0 & 197 \\
\hline 4 & Bangka Belitung & 440 & 14 & 454 & 331 & 2 & 333 & 6 & 0 & 6 \\
\hline 5 & Bengkulu & 774 & 11 & 785 & 571 & 14 & 585 & 37 & 1 & 38 \\
\hline 6 & Di Yogyakarta & 2904 & 56 & 2960 & 2192 & 31 & 2223 & 76 & 2 & 78 \\
\hline 7 & Dki Jakarta & 83,372 & 943 & 84,315 & 68,260 & 850 & 69,110 & 1834 & 21 & 1855 \\
\hline 8 & Jambi & 715 & 45 & 760 & 304 & 5 & 309 & 14 & 2 & 16 \\
\hline 9 & Jawa Barat & 26,259 & 504 & 26,763 & 15,966 & 563 & 16,529 & 527 & 2 & 529 \\
\hline 10 & Jawa Tengah & 25,261 & 412 & 25,673 & 17,887 & 210 & 18,097 & 1472 & 10 & 1482 \\
\hline 11 & Jawa Timur & 46,095 & 310 & 46,405 & 39,607 & 306 & 39,913 & 3374 & 20 & 3394 \\
\hline 12 & Kalimantan Barat & 1108 & 28 & 1136 & 879 & 30 & 909 & 9 & 0 & 9 \\
\hline 13 & Kalimantan Timur & 10,203 & 135 & 10,338 & 7038 & 182 & 7220 & 394 & 10 & 404 \\
\hline 14 & Kalimantan Tengah & 3866 & 24 & 3890 & 3141 & 8 & 3149 & 139 & 0 & 139 \\
\hline 15 & Kalimantan Selatan & 10,816 & 81 & 10,897 & 9363 & 142 & 9505 & 438 & 1 & 439 \\
\hline 16 & Kalimantan Utara & 629 & 3 & 632 & 555 & 4 & 559 & 5 & 0 & 5 \\
\hline 17 & Kepulauan Riau & 2450 & 0 & 2450 & 1826 & 0 & 1826 & 60 & 0 & 60 \\
\hline 18 & NTB & 3485 & 28 & 3513 & 2770 & 22 & 2792 & 203 & 2 & 205 \\
\hline 19 & Sumatera Selatan & 6614 & 63 & 6677 & 4937 & 65 & 5002 & 367 & 3 & 370 \\
\hline 20 & Sumatera Barat & 7824 & 295 & 8119 & 4386 & 167 & 4553 & 162 & 4 & 166 \\
\hline 21 & Sulawesi Utara & 4685 & 19 & 4704 & 3840 & 35 & 3875 & 179 & 1 & 180 \\
\hline 22 & Sumatera Utara & 11,064 & 95 & 11,159 & 8237 & 164 & 8401 & 459 & 2 & 461 \\
\hline 23 & Sulawesi Tenggara & 3356 & 63 & 3419 & 2273 & 36 & 2309 & 64 & 1 & 65 \\
\hline 24 & Sulawesi Selatan & 16,298 & 101 & 16,399 & 13,581 & 111 & 13,692 & 429 & 2 & 431 \\
\hline 25 & Sulawesi Tengah & 528 & 11 & 539 & 335 & 20 & 355 & 21 & 0 & 21 \\
\hline 26 & Lampung & 1089 & 0 & 1089 & 748 & 17 & 765 & 38 & 1 & 39 \\
\hline 27 & Riau & 9226 & 204 & 9430 & 5790 & 66 & 5856 & 202 & 6 & 208 \\
\hline 28 & Maluku Utara & 2082 & 0 & 2082 & 1831 & 33 & 1864 & 74 & 0 & 74 \\
\hline 29 & Maluku & 3272 & 0 & 3272 & 2014 & 0 & 2014 & 41 & 0 & 41 \\
\hline 30 & Papua Barat & 2754 & 100 & 2854 & 1393 & 87 & 1480 & 39 & 0 & 39 \\
\hline 31 & Papua & 7312 & 116 & 7428 & 4158 & 0 & 4158 & 107 & 0 & 107 \\
\hline 32 & Sulawesi Barat & 868 & 10 & 878 & 484 & 8 & 492 & 11 & 0 & 11 \\
\hline 33 & NTT & 532 & 19 & 551 & 343 & 6 & 349 & 7 & 0 & 7 \\
\hline 34 & Gorontalo & 2931 & 2 & 2933 & 2443 & 106 & 2549 & 78 & 0 & 78 \\
\hline & TOTAL & 320,564 & 4094 & 324,658 & 244,060 & 3607 & 247,667 & 11,580 & 97 & 11,677 \\
\hline
\end{tabular}


not fully explained, although there have been many studies on previous virus species that show effects on male reproduction [10].

\section{Effects of SARS-CoV-2 on the Female Reproductive System}

Until now, the damage of female reproductive system due to COVID-19 patients has not been reported. There is evidence that the renin-angiotensin (Ang)aldosterone system is involved in female reproductive processes such as folliculogenesis, steroidogenesis, oocyte maturation, and during ovulation. Reis et al. confirmed the presence of the Ang- (1-7)-axis MasACE2 receptor, and the ACE2 marker at all stages of follicular maturation in the human ovary. ACE2 is also found in the endometrium, in epithelial cells higher than stromal cells, and ACE2 expression changes according to the phase of the menstrual cycle, becoming more during the secretory phase than in the proliferative phase; this may interfere with local Ang-II homeostasis and regulate endometrial regeneration [10], [11], [12]

Furthermore, the previous studies have shown that ACE2 is expressed in the ovaries and granulosa cells of cattle and mice, is regulated by gonadotropins, and is involved in follicular development. Hence, it can be said that the possibility of the SARS-CoV-2 mechanism can affect fertility on female, namely: (1) SARS-CoV-2 can harm ovarian tissue and granulosa cells, and reduce ovarian function and oocyte quality, can make infertility or miscarriage; and (2) SARSCoV-2 also damage the endometrial epithelium and affect early embryo implantation. However, there is still little evidence explaining the effects of SARS-CoV-2 on the Fallopian tubes, so it needs to be more attention in the future [10], [11].

\section{ACE2 in the Ovary}

ACE2 is present in stromal cells and granulosa cells and oocytes in the ovaries of immature mice, whose expression is increased in antral and pre-ovulatory follicles. In theca cells and bovine granulosa cells, ACE2 is also present. Transcription of ACE2 mRNA is detectable in the ovaries of women from reproductive age to postmenopausal women. Based on the analysis of ACE2 data from the Gene Card database, it was found that ACE2 was most expressed in the ovaries. Meanwhile, the data obtained from Bgee showed that the level of ACE2 expression in oocytes was relatively high. Therefore, the ovaries and oocytes may be potential targets of nCoV-2019 (Figure 2) [2], [9].

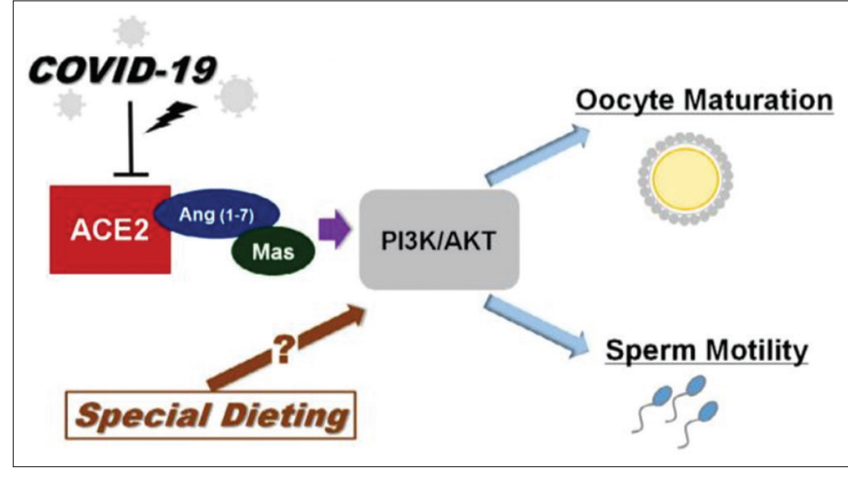

Figure 2: Illustration coronavirus disease 2019 causes infertility by impairing oocyte maturation [13]

\section{ACE2 in Uterine and Vagina}

ACE2 mRNA has been identified in the uterus of humans and mice. ACE2 mRNA is more common in epithelial cells than in stromal cells, and higher in the secretory phase than in the proliferative phase. Moreover, it has been confirmed the presence of ACE2 in the uterus and vagina based on data analysis from the Human Protein Atlas and Gene Card Database. It is noteworthy, however, that there are reports which found that the transmission rate of infection was quite high among the sexual partners of 35 women with nCoV2-2019 positive, which may explain the possibility of transmission through sexual contact. However, transmission by sexual contact still requires further research [2].

\section{ACE2 in Pregnancy}

ACE2 is widely revealed in the human placenta. In the placental villi, ACE2 is revealed in the syncytiotrophoblast, cytotrophoblast, smooth muscle, and vascular endothelium of the primary and secondary villi. In the maternal stroma, ACE2 is expressed in invading trophoblasts and in intravascular trophoblasts, as well as in decidual cells. ACE2 is also found in arterial and venous endothelium and umbilical cord smooth muscle. Hence, ACE2 reaches its highest level in early pregnancy. Lately, early-onset nCoV2019 infection was found in infants based on positive nasopharyngeal and anal swabs on days 2 and 4 of birth and an infant born from a mother with COVID-19 positive had elevated IgM antibodies $2 \mathrm{~h}$ after birth. The identification of nCoV-2019 in human airway epithelial cells requires at least $96 \mathrm{~h}$ for culture, there is speculation that intrauterine transmission of $\mathrm{nCoV}$ 2019 may occur and may allow the fetus to become infected during pregnancy [2].

One of three breast milk samples were positive for nCoV-2019 when tested for nucleic acid, showing 
the possibility of transmission through breastfeeding. Although there was no virus in breast milk, transmission by contact during breastfeeding must be taken into account. Given the weak immune system in newborns, it is highly recommended that pregnant patients who are positive for nCoV-2019 should do breastfeeding, or start breastfeeding after 14 days of self-isolation and symptoms improve. However, considering the benefits of breast milk in lowering the risk of respiratory, gastrointestinal infections, sudden infant death syndrome, and diabetes in infants, breastfeeding may not be completely prohibited. However, it was reported that of two postpartum women who were diagnosed with COVID-19 and did not wear a mask while breastfeeding, their newborns tested positive [10].

\section{Gynecological Surgery during the COVID-19 Pandemic}

Surgery on patients who are suspected or confirmed positive for COVID-19 is a high-risk procedure. In infected patients, COVID-19 can be found in their body cavities. Aerosols generated in the operating room during surgery can contain viruses or particles that are thought to survive in the aerosol for at least $3 \mathrm{~h}$ (Figure 3). During surgery, the droplets may be exposed and theoretically could infect the surgical team involved at that time. However, there are several operations on gynecological disorders that cannot be delayed [14], [15] (Table 2).

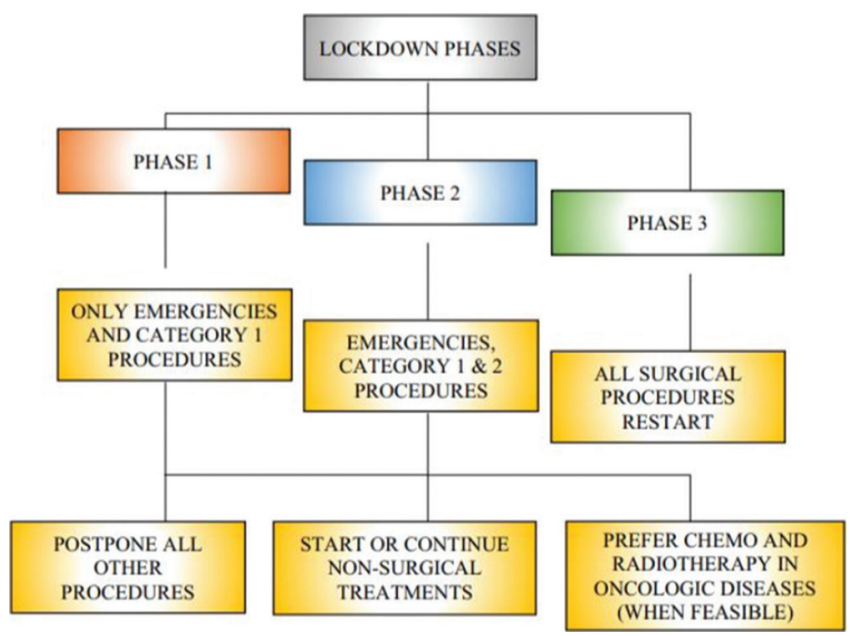

Figure 3: Guide to priority gynecological operations in 3-phase lockdown during the coronavirus disease 2019 pandemic [14]

Table 2: Operation triage category [14]

\begin{tabular}{clc}
\hline Category & \multicolumn{1}{c}{ Description } & $\begin{array}{c}\text { Desirable Maximum } \\
\text { Waiting Time }\end{array}$ \\
\hline Urgent & $\begin{array}{l}\text { Has the potential to deteriorate quickly to the point where it } \\
\text { may become an emergency }\end{array}$ & Within 30 days \\
Semi-urgent & $\begin{array}{l}\text { Causes pain, dysfunction, or disability } \\
\text { Unlikely to deteriorate quickly } \\
\text { Unlikely to become an emergency }\end{array}$ & Within 60 days \\
Elective & $\begin{array}{l}\text { - Causes pain, dysfunction, or disability } \\
\text { Unlikely to deteriorate quickly }\end{array}$ & Within 365 days \\
\hline
\end{tabular}

\section{Telemedicine during the COVID-19}

\section{Pandemic}

Providing primary health care during this pandemic seemed to be challenging as health-care services are being interrupted due to inadequate protective gears, lockdown, and also the risk of infection spread to patients and medical practitioners. To make a better decrease and manage the spread of coronavirus, hospitals need to improve the efficiency of their medical system by replacing physical treatments with digital technologies [16]

Telemedicine promotes social distancing and helps medical centers in managing prolonged waiting times and risk of disease progression. However, only few physicians and patients are adequately educated on how best practice to utilize these digital services. Hence, there is a need to make a guidelines and recommendation to educate both physicians and patients on how they can use telemedicine and virtual care effectively [16].

In Indonesia, telemedicine activities have been implemented according to the POGI guideline called TeleMed POGI where TeleMed POGI refers to the Minister of Health Regulation number 20/2019 and Regulation of the Indonesian Medical Council number $74 / 2020$, which state that providing of remote healthcare services by the obstetricians and gynecologists to patients is used by information and communication technology [17].

The POGI TeleMed service is limited to $30 \mathrm{~min}$ per patient consultation, however, this service can facilitate the administration of mild drugs prescription to pharmacies in non-emergency complaints of obstetrics and gynecology. TeleMed POGI is not allowed to handle emergency complaints and cases, as well as oncologygynecology cases. Cases that can be served by TeleMed POGI are non-emergency cases including [17]:

- Mild pregnancy-related complaints such as delayed menstruation, infertility, vaginal discharge, and pregnancy control without complaint

- $\quad$ Mild complaints related to the menstrual cycle such as menstrual pain and irregular cycles

- $\quad$ Mild complaints related to the urinary tract and genitalia such as urinary tract infections and mild degree of pelvic organ prolapse

Mild post-operative complaints such as control of the anatomical pathology results

Mild complaints related to precancerous lesions such as control of pap smear results

- Consultation on laboratory and radiological results in obstetrics and gynecology.

At least 59 hospitals (including RSCM Jakarta, RSUD Hasan Sadikin Bandung, RSUP Haji Adam Malik Medan, RSUD Sorong Papua, and many others) and 173 primary health centers in Indonesia have been participated in telemedicine services and are 
connected to each other. However, there are several limitations of telemedicine. It might not be ideal if focusing sensitive topics, especially if there is patient's inconvenience or concern for privacy. There is also a certain situation in which in-person visits are more suitable due to urgency, a person's underlying health conditions, or the fact that a physical examination or laboratory testing is needed for medical decision making. Limited access to technological devices or connectivity may make telemedicine not suitable for some people, especially for those living in rural environment [18], [19].

\section{Assisted Reproductive Technology During the COVID-19 Pandemic}

In the early stages of the pandemic, the American Society for Reproductive Medicine (ASRM) and European Society of Human Reproduction and Embryology (ESHRE) recommend discontinuation of infertility therapy except for the urgent cases mostly. In March 2020, the ESHRE recommended "to avoid getting pregnant at this time." For undergoing treatment patients, they suggest "considering delaying pregnancy by freezing the embryo or oocytes to delay embryo transfer." The ASRM also issued a statement delaying "non-urgent" treatment and embryo transfer whenever possible [10], [20], [21].

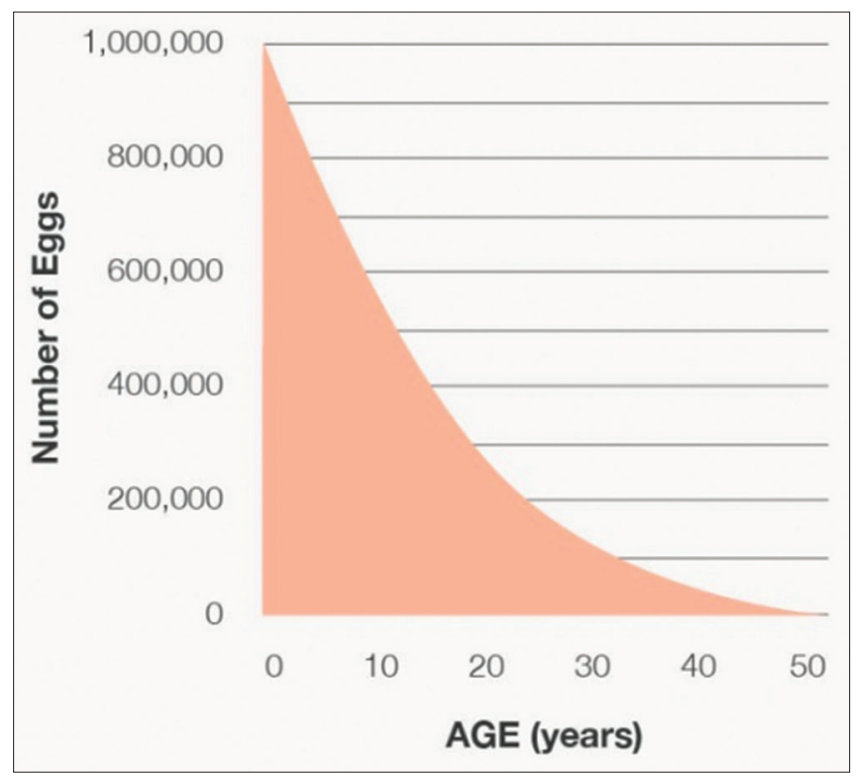

Figure 4: Egg count overtime [23]

This condition led to have significant impacts on psychological status and live birth. It is reported that $38 \%$ of patients with failed in vitro fertilization (IVF) cycles of 2 were detected with anxiety or depression. About $37.4 \%$ of patients declared that they would like

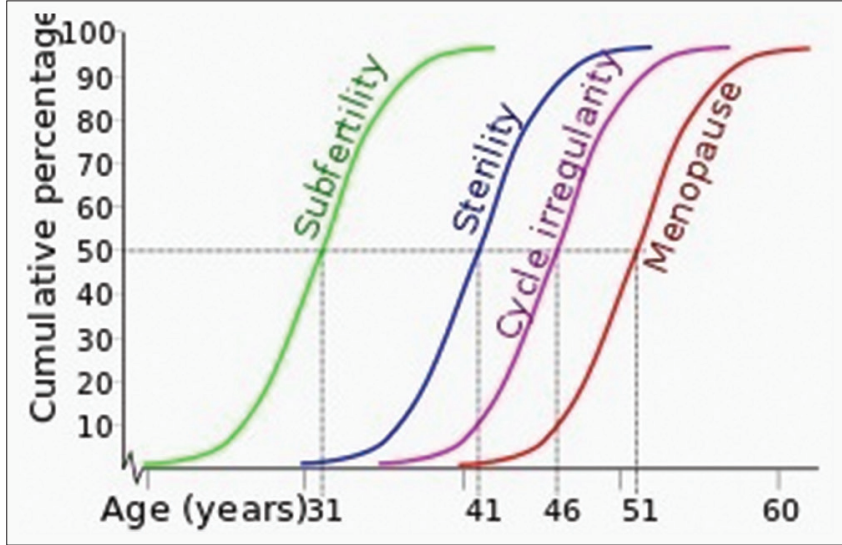

Figure 5: Age and reproductive in woman [23]

to undergo the IVF treatment despite the COVID-19 pandemic. The unsustainable of fertility treatment for even 1 month in the USA could make in 369 fewer women having live birth, due to the mount in patients' age during the lockdown [22].

Infertility is a time-sensitive problem, due to its correlation with decreased of egg quality (Figure 4). The optimal age for fertility rate is considered to be in range of 18-31 years old, subfertility stage is $31-41$ years, while woman at $41-51$ years is thought to have sterility and irregular cycle, which means she is in perimenopause state. The average age of menopause is 47.5 years according to Indian Menopause Society (Figure 5) [22], [23].

However, recently, with mitigation strategies that have worked in several areas and the presence of additional data, as well as resistance to this policy, infertility therapy has resumed. ASRM, ESHRE, and International Federation of Fertility Societies have come asserted the importance of serial reproductive care during the COVID-19 pandemic [20], [23], [24], [25].

There is no evidence to suggest the presence of virus in follicular fluid. Data on the infectivity potency of semen are controversial. Even though the presence of SARS-CoV-2 in the semen of infected and hospitalized patients has been proven, no conclusions about transmission can be ascertained and further studies are needed to confirm this hypothesis (Figure 6) [10], [26].

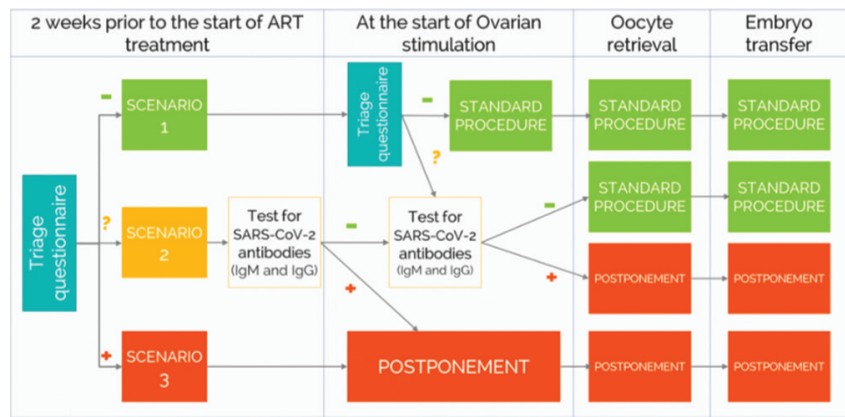

Figure 6: Summary of the infertility therapy cycle [24] 


\section{Conclusion}

COVID-19 caused by SARS-CoV-2 which is an acute infectious disease that affects the respiratory system mostly, but can also attack the reproductive system. This is because this virus enters the target cells through the glycoprotein spike SARS-CoV-2 (S) which binds to the host's ACE2 receptor. And host cellular proteases such as TMPRSS2 then cleavage viral $S$ protein which allows permanent fusion of the viral and host cell membranes.

In the reproductive organs, ACE2 was also expressed predominantly in spermatogonia, Leydig cells, and Sertoli cells, while TMPRSS2 was revealed only in spermatogonia and spermatids. ACE2 is also found in the ovaries, uterus, vagina, and placenta. Hence, viral infection can also impact reproductive function if the cells of the male and/or female reproductive systems also shown ACE2.

Given that this pandemic has only occurred in early March 2020, so there are still little data being reported, therefore, further investigation with sufficient timeframes is needed regarding the effects of COVID-19 on this reproductive system so that clear evidence can be obtained so that appropriate action can be taken.

\section{References}

1. Stanley KE, Thomas E, Leaver M, Wells D. Coronavirus disease (COVID- 19) and fertility: Viral host entry protein expression in male and female reproductive tissues. Fertil Steril. 2020;114(1):33-43. https://doi.org/10.1016/j. fertnstert.2020.05.001 PMid:32622411

2. Jing Y, Run-Qian L, Hao-Ran W, Hao-Ran C, Ya-Bin L, Yang G, et al. Potential influence of COVID-19/ACE2 on the female reproductive system. Mol Hum Reprod. 2020;26(6):367-73. https://doi.org/10.1093/molehr/gaaa030

PMid:32365180

3. World Health Organization, WHO Coronavirus Disease (COVID-19) Dashboard. Geneva: World Health Organization; 2020. Available from: https://www.covid19.who.int/table. [Last accessed on 2021 May 26]

4. Satuan Tugas Penanganan COVID-19. Situasi Virus COVID-19 di Indonesia; 2020. Available from: https://www.covid19.go.id. [Last accessed on 2021 May 26].

5. Dinas Kesehatan Kota Medan. Data Generaal Terkait COVID19 di Kota Medan. 2020. Available from: https://www.covid19. pemkomedan.go.id/index.php?page=statmd. [Last accessed on 2021 May 26].

6. Zupin L, Pascolo L, Zito G, Ricci G, Crovella S. SARS-CoV-2 and the next generations: Which impact on reproductive tissues? J Assist Reprod Genet. 2020;37(10):2399-403. https:// doi.org/10.1007/s10815-020-01917-0

PMid:32783136

7. Kai H, Kai M. Interactions of coronaviruses with ACE2, angiotensin II, and RAS inhibitors lessons from available evidence and insights into COVID-19. Hypertens Res. 2020;43:648-54. https://doi.org/10.1038/s41440-020-0455-8

8. Khalili MA, Leisegang K, Majzoub A, Finelli R, Selvam MK, Henkel R, et al. Male fertility and the COVID-19 pandemic: Systematic review of the literature. World $\mathrm{J}$ Mens Health. 2020;38(4):506-20. https://doi.org/10.5534/wjmh.200134 PMid:32814369

9. Illiano E, Trama F, Costantini E. Could COVID-19 have an impact on male fertility? Andrologia. 2020;52(6):e13654. https:// doi.org/10.1111/and.13654

PMid:32436229

10. Pascolo L, Zito G, Zupin L, Luppi S, Giolo E, Martinelli M, et al Renin angiotensin system, COVID-19 and male fertility: Any risk for conceiving? Microorganisms. 2020;8(10):1492. https://doi. org/10.3390/microorganisms8101492 PMid:32998451

11. Li R, Yin T, Fang F, Li Q, Chen J, Wang Y, et al. Potential risks of SARS-Cov-2 infection on reproductive health. Reprod Biomed Online. 2020;41(1):89-95. https://doi.org/10.1016/j. rbmo.2020.04.018 PMid:32466994

12. Goad J, Rudolph J, Rajkovic A. Female reproductive tract has low concentration of SARS-CoV2 receptors. bioRxiv. 2020;2020:163097. https://doi.org/10.1101/2020.06.20.163097 PMid:32607512

13. Tsuji A, Ikeda Y, Murakami M, Matsuda S. COVID-19, an infertility risk? Clin Obstet Gynecol Reprod Med 2020;6:1-1. https://doi.org/10.15761/cogrm.1000291

14. Chiofalo B, Baiocco E, Mancini E, Vocaturo G, Cutillo G, Vincenzoni $C$, et al. Practical recommendations for gynecologic surgery during the COVID-19 pandemic. Int J Gynecol Obstet. 2020;150(2):146-50. https://doi.org/10.1002/ijgo.13248

15. Grimes CL, Balk EM, Crisp CC, Antosh DD, Murphy M, Halder GE, et al. A guide for urogynecologic patient care utilizing telemedicine during the COVID-19 pandemic: Review of existing evidence. Int Urogynecol J. 2020;31(6):1063-89. https://doi.org/10.1007/s00192-020-04314-4 PMid:32342112

16. Jnr BA. Use of telemedicine and virtual care for remote treatment in response to COVID-19 pandemic. J Med Syst. 2020;44(7):132. https://doi.org/10.1007/s10916-020-01596-5 PMid:32542571

17. Indonesian Association of Obstetrics and Gynecology. POGl's Telemedicine Guide in Recommendations for Corona Virus (COVID-19). Indonesia: Indonesian Association of Obstetrics and Gynecology; 2020

18. Telemedicine Indonesia; 2020. Available from: https://www. temenin.kemkes.go.id/\#. [Last accessed on 2020 Oct 13].

19. Vidal-Alaball J, Acosta-Roja R, Hernández NP, Luque US, Morrison D, Pérez SN, et al. Telemedicine in the face of the COVID-19 pandemic. Aten Primaria. 2020;52(6):418-22. https:// doi.org/10.1016/j.aprim.2020.04.003

PMid:32402477

20. Veiga A, Gianaroli L, Ory S, Horton M, Feinberg E, Penzias A. Assisted reproduction and COVID-19: A joint statement of ASRM, ESHRE and IFFS*. Fertil Steril. 2020;114(3):484-5. https://doi.org/10.1016/j.fertnstert.2020.06.044 PMid:32674808

21. Alviggi C, Esteves SC, Orvieto R, Conforti A, La Marca A, Fischer $\mathrm{R}$, et al. COVID-19 and assisted reproductive technology services: Repercussions for patients and proposal for individualized clinical management. Reprod Biol Endocrinol. 2020;18(1):45.

PMid:32404170 
22. Barra F, La Rosa VL, Vitale SG, Commodari E, Altieri M, Scala C, et al. Impact of COVID-19 pandemic on the psychological status of infertile patients who had in vitro fertilization treatment interrupted or postponed: A cross-sectional study. Authorea Preprints. 2020. https://doi.org/10.22541/au.159809461.19005892

23. Siregar MF. Perimenopausal and postmenopausal complaints in paramedics assesed by menopause rating scale in Indonesia. J Dent Med Sci. 2014;13(12):38-42. https://doi. org/10.9790/0853-131213842

24. ESHRE Covid-19 Working Group. ESHRE Guidance for
Recommencing ART Treatments. ESHRE Website; 2020.

25. Peivandi S, Razavi A, Shafiei S, Zamaniyan M, Orafaie A, Jafarpour $\mathrm{H}$. Evaluation of attitude among infertile couples about continuing assisted reproductive technologies therapy during novel coronavirus outbreak. medRxiv. 2020; https://doi. org/10.1101/2020.09.01.20186320

26. Turocy JM, Robles A, Hercz D, D'alton M, Forman EJ, Williams Z. The emotional impact of the ASRM guidelines on fertility patients during the Covid-19 pandemic. Medrxiv. 2020. https://doi.org/10.1101/2020.03.29.20046631 